\title{
Toxicological effect of pretilachlor on some physiological processes of cyanobacterium Synechocystis sp. strain PUPCCC 64
}

\author{
Davinder Pal Singh*, Jasvirinder Singh Khattar, Alka, Gurdeep Kaur, Yadvinder Singh ${ }^{1}$ \\ Department of Botany, Punjabi University, Patiala-147002, Punjab, India. \\ ${ }^{1}$ Department of Botany and Environment Science, Sri Guru Granth Sahib World University, Fatehgarh Sahib-140406, Punjab, India.
}

\begin{tabular}{|c|c|}
\hline ARTICLE INFO & ABSTRACT \\
\hline $\begin{array}{l}\text { Article history: } \\
\text { Received on: } 21 / 11 / 2015 \\
\text { Revised on: } 07 / 12 / 2015 \\
\text { Accepted on: } 26 / 12 / 2015 \\
\text { Available online: } 09 / 01 / 2016\end{array}$ & $\begin{array}{l}\text { The toxicological effects of herbicide Pretilachlor on photosynthesis, respiration and nitrogen assimilation of the } \\
\text { unicellular cyanobacterium Synechocystis sp. PUPCCC } 64 \text { has been studied. Treatment of the test organism with } \\
\text { Pretilachlor }\left(10,15 \text { and } 20 \mathrm{mg} \mathrm{L}^{-1}\right) \text { negatively affected its growth, soluble proteins, photosynthetic pigments, } \\
\text { photosynthesis and respiration in a dose dependent manner. Soluble cellular proteins decreased in range of 14- } \\
52 \% \text {. Although herbicide affected all the photosynthetic pigments, maximum effect was observed on carotenoids } \\
(76 \% \text { decrease) followed by allophycocyanin }(61 \% \text { decrease). Pretilachlor caused } 49 \% \text { decrease in }\end{array}$ \\
\hline $\begin{array}{l}\text { Key words: } \\
\text { Pretilachlor, Synechocystis } \\
\text { sp., photosynthesis, } \\
\text { respiration, nitrogen } \\
\text { metabolism. }\end{array}$ & $\begin{array}{l}\text { photosynthetic rates. Studies on photochemical activity revealed that the herbicide affected both photosystems } \\
\text { (PS-I and PS-II) as well as whole chain photosynthetic electron transport activity. The rate of respiration } \\
\text { decreased in the range of } 24-59 \% \text { in the presence of herbicide. Decrease in photosynthetic as well as respiration } \\
\text { rates ultimately resulted in decreased nitrogen assimilation as revealed by } 50 \% \text { reduction each in nitrate and } \\
\text { nitrite uptake and } 33 \% \text { reduction in ammonium uptake along with } 21-32 \% \text { decrease in nitrate reductase, nitrite } \\
\text { reductase and glutamine synthetase activity. The main toxic effect of Pretilachlor on the test organism appears to } \\
\text { be on photosynthesis, and the effect on other physiological processes is a consequence of toxic effects of } \\
\text { Pretilachlor on photosynthetic machinery. }\end{array}$ \\
\hline
\end{tabular}

\section{INTRODUCTION}

It is estimated that by 2050 the world population will be approximating 9 million and to provide food to these population will be a major challenge for human being [1]. The production of sufficient food for the world's population in 2050 will be possible only if agriculture shall be based on high-tech seeds and low-tech farming practices [2]. Rice is the most important cereal crop in the developing world and a staple food for more than half of the world's population. Research and development programmes in rice are crucial for the development of strategies to increase global food security [3]. The application of herbicides in rice fields to eradicate weeds allowing rice plant to grow and gain a competitive advantage is one of the strategies [4]. However, the use of herbicides in rice fields results in serious environmental contamination threatening the integrity and stability of ecosystems [5]. The cyanobacteria, being an important component of microbial community in rice field ecosystem, significantly contribute to fertility of the soil as natural biofertilizer $[6,7,8]$. These microorganisms increase organic matter, water holding capacity, nitrogen status and

* Corresponding Author

Email:dp.khokhar@rediffmail.com

Phone: 0175-3046265(O), 919876160834 (M) release vitamins or plant growth stimulating hormones, extracellular polysaccharides etc. $[9,10]$ and even some metabolize pesticides $[11,12]$. Thus, supplementation of cyanobacterial biofertilizer is considered to be a good management of paddy field since this not only adds to fertility of the soil but is also ecofriendly. Detailed investigations on deleterious effects of herbicides on cyanobacteria are required, since the utilization of cyanobacterial biofertilizer in rice fields requires the strains tolerant to a variety of routinely used agrochemicals including herbicides. Effects of some herbicides like Thiobencarb [13], Atrazine, Molinate and Bentazon [14, 15], Butachlor [16,17], Glyphosate, 2-methyl-4-chlorophenoxyacetic acid (MCPA) and 3(3,4-dichlorophenyl)-1,1-dimethylurea (DCMU) [18,19] and Anilofos [12, 20] on few cyanobacteria have been reported. Pretilachlor (2-chloro-N-(2,6-diethylphenyl)-N-(2-propoxyethyl) acetanilide) is the active chemical of the commercial grade herbicide Rifit, which is used on a large scale in the rice fields of Punjab state. This herbicide belongs to the chloroacetanilide group and is used as pre-emergence and early post-emergence herbicide for the control of annual grasses and some broad-leaved weeds such as Echinocloa crusgalli and Ischaemum rugosum in both seeded and transplanted fields at the rate of $300 \mathrm{gm}$ active ingredient per acre [21, 22]. The chemical structure of Pretilachlor is shown in figure 1 . 
The aim of the present investigation was to study the toxicological effect of Pretilachlor on photosynthesis, respiration and nitrogen assimilation of a unicellular cyanobacterium Synechocystis sp. strain PUPCCC 64.

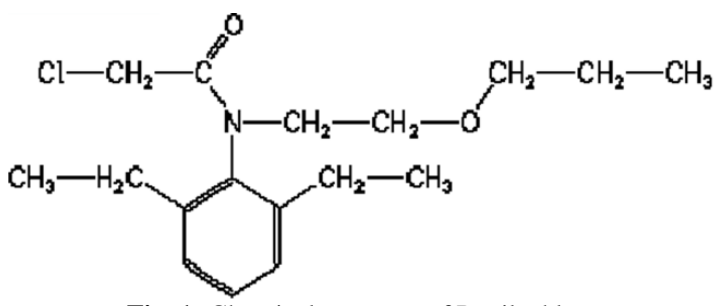

Fig. 1: Chemical structure of Pretilachlor.

\section{MATERIALS AND METHODS}

\subsection{Organism and Culture Conditions}

The cyanobacterium Synechocystis sp. strain PUPCCC 64 was isolated from paddy fields of village Derabassi $\left(30^{\circ} 58^{\prime} 72^{\prime \prime}\right.$ $\mathrm{N} ; 76^{\circ} 8^{\prime} 28^{\prime \prime}$ E) of district Mohali, Punjab, India [11]. The organism was grown in slightly modified Chu-10 medium [23] supplemented with micronutrients. One litre nutrient medium contained $0.232 \mathrm{~g} \mathrm{CaCl}_{2} .2 \mathrm{H}_{2} \mathrm{O}, 0.025 \mathrm{~g} \mathrm{MgSO}_{4} \cdot 7 \mathrm{H}_{2} \mathrm{O}, 0.02 \mathrm{~g}$ $\mathrm{Na}_{2} \mathrm{CO}_{3}, 0.044 \mathrm{~g} \mathrm{Na}_{2} \mathrm{SiO}_{3} .5 \mathrm{H}_{2} \mathrm{O}, 0.01 \mathrm{~g} \mathrm{~K}_{2} \mathrm{HPO}_{4}, 0.0035 \mathrm{~g}$ of ferric citrate and citric acid and $1 \mathrm{~g} \mathrm{KNO}_{3}$. Stock and experimental cultures were maintained in a culture room at $28 \pm 2{ }^{\circ} \mathrm{C}$ and illuminated with fluorescent tubes giving photon flux of $44.5 \mu \mathrm{mol}$ $\mathrm{m}^{-2} \mathrm{~s}^{-1}(\mu \mathrm{E})$ with light/dark cycle of $14 / 10 \mathrm{~h}$. Exponentially growing (10 days old) cultures were used throughout the study and each experiment was repeated thrice.

\subsection{Tolerance limit of test organism to Pretilachlor}

The tolerance limit of Synechocystis towards herbicide was determined by growing it in graded concentrations of Pretilachlor (10 to $40 \mathrm{mg} \mathrm{L}^{-1}$ ). These concentrations were prepared in $250 \mathrm{~mL}$ Erlenmeyer flasks containing $100 \mathrm{~mL}$ Chu-10 medium from the stock solution of commercial grade Pretilachlor $(50 \%$ Emulsifiable Concentrate). Exponentially growing stock cultures, after two washings with sterilized double distilled water, were inoculated in herbicide containing medium to get an initial absorbance of 0.1 at $680 \mathrm{~nm}\left(110 \times 10^{6}\right.$ cells $\mathrm{mL}^{-1}$ culture $)$. At regular intervals of $2 \mathrm{~d}$, extending up to $12 \mathrm{~d}, 10 \mathrm{~mL}$ samples were withdrawn and growth was measured as an increase in absorbance of the cultures at $680 \mathrm{~nm}$ with the help of spectrophotometer (Spectronic 20D+, USA). The per cent inhibition in growth of the organism was calculated by taking growth data of control culture on day 6 as $100 \%$. Specific growth rate constant and generation time were determined from the linear portion of growth curve following Myers and Kratz [24]. Protein content of the cultures was determined as per the method of Lowry et al. [25].

\subsection{Effect of Pretilachlor on photosynthetic pigments}

Ten milliliter of experimental cultures were withdrawn and number of cells per $\mathrm{mL}$ of cultures were counted. The cells were centrifuged at $5000 \mathrm{~g}$, washed thrice with double distilled water and to the cell pellet same volume of $80 \%$ acetone was added. The mixture was shaken vigorously and incubated in a refrigerator for $12 \mathrm{~h}$. The contents were centrifuged at $5000 \mathrm{~g}$, attained the same volume of supernatant by adding sufficient volume of $80 \%$ acetone and the absorbance was taken at $660 \mathrm{~nm}$, $645 \mathrm{~nm}$ and $450 \mathrm{~nm}$.

Chlorophyll $a(\mathrm{Chl} a)$ was calculated following Holm [26] as per the equation given below:

$$
\text { Chl } a\left(\mu \text { g per } 10^{6} \text { cells }\right)=\left(9.76 \times \mathrm{A}_{660}\right)-\left(0.99 \times \mathrm{A}_{645}\right)
$$

where, $\mathrm{A}_{660}=$ absorbance at $660 \mathrm{~nm}, \mathrm{~A}_{645}=$ absorbance at $645 \mathrm{~nm}$

Total Carotenoids were quantified following Myres and Kratz [24] as per the equation given below:

$$
\text { Carotenoids }\left(\mathrm{mg} \text { per } 10^{6} \text { cells }\right)=\mathrm{A}_{450} / 200
$$

Where, $\mathrm{A}_{450}=$ absorbance at $450 \mathrm{~nm}$

The phycobiliproteins were extracted in phosphate buffer (50 mM, pH 7.0) by freeze-thaw method. Pellet of cyanobacterial cells, obtained after centrifugation at $5000 \mathrm{~g}$, was washed and re-suspended in phosphate buffer containing lysozyme $(1 \mathrm{mg} \mathrm{mL}$ ${ }^{1}$ ). The mixture was incubated at $37{ }^{\circ} \mathrm{C}$ in a water bath for $1 \mathrm{~h}$ with occasional stirring. The spheroplasts obtained were gently washed by centrifugation at $5000 \mathrm{~g}$ and resuspended in phosphate buffer. The contents were then subjected to 10-12 freeze-thaw cycles till all the water soluble pigments were released from the cells. Absorbance of supernatant, after centrifugation at $5000 \mathrm{~g}$, was noted at $565 \mathrm{~nm}, 615 \mathrm{~nm}$ and $652 \mathrm{~nm}$ and phycobiliproteins ( $\mu \mathrm{g}$ per $10^{6}$ cells) were quantified following Bennet and Bogorad [27] as per the equations given below.

$$
\begin{gathered}
\text { Phycocyanin }=\frac{\left(\mathrm{A}_{615}\right)-\left(0.474 \times \mathrm{A}_{652}\right)}{5.34} \\
\text { Allophycocyanin }=\frac{\left(\mathrm{A}_{652}\right)-\left(0.208 \times \mathrm{A}_{615}\right)}{5.09} \\
\text { Phycoerythrin }=\frac{\left(\mathrm{A}_{565}\right)-(2.41 \times \mathrm{PC})-(0.849 \times \mathrm{APC})}{5.62}
\end{gathered}
$$

\subsection{Measurements of photosynthetic, respiratory and photochemical activities}

Rates of photosynthesis and dark respiration were measured in terms of oxygen evolution and oxygen consumption in light and dark, respectively. Pretilachlor treated and untreated control cultures were concentrated by centrifugation at $5000 \mathrm{~g}$ and thick suspension of biomass (10 $\mu \mathrm{g}$ chl $\left.a \mathrm{~mL}^{-1}\right)$ was taken in a reaction vessel fitted with oxygen electrode of oxygen analyzer (Model 5300 A, YSI Bioanalytical Products, USA). Increase in amount of dissolved oxygen was followed for $5 \mathrm{~min}$ after switching on light source ( $225 \mu \mathrm{E}$ on the surface of vessel). The rate of dark respiration was measured for $10 \mathrm{~min}$ by following the decrease in dissolved oxygen when the reaction vessel was incubated in dark.

Photochemical activities of cultures were measured according to the method of Chen et al. [28]. Exponentially growing culture treated with 10,15 and $20 \mathrm{mg}$ Pretilachlor $\mathrm{L}^{-1}$ for 
$6 \mathrm{~h}$ and untreated cultures were harvested by centrifugation at $5000 \mathrm{~g}$ and re-suspended in fresh Chu-10 medium. Photochemical activities of whole cells were assayed under light intensity of 225 $\mu \mathrm{E}$ and at $28 \pm 2{ }^{\circ} \mathrm{C}$ using oxygen electrode. PS-II activity was measured as oxygen evolution with $\mathrm{H}_{2} \mathrm{O}$ as the electron donor and $p$-benzoquinone ( $p$-BQ) as the electron acceptor in $3 \mathrm{~mL}$ culture medium containing $25 \mathrm{mM}$ bis-tris propane (BTP, $\mathrm{pH} 7.8$ ) and 1 $\mathrm{mM} p$-BQ. PS-I activity was measured as light dependent oxygen uptake in $25 \mathrm{mM}$ BTP (pH 7.8), containing $0.1 \mathrm{mM} \mathrm{2,6-}$ dichlorophenol indophenol (DCPIP) as the electron donor, $5 \mathrm{mM}$ ascorbate as reductant to reduce DCPIP to DCPIPH $\left._{2}\right), 0.1 \mathrm{mM}$ methyl viologen (MV) as the electron acceptor, $1 \mathrm{mM} \mathrm{NaN}_{3}$ (inhibiting respiration), and $10 \mu \mathrm{M}$ DCMU (inhibiting PS-II activity). The whole chain photosynthetic electron transport activity (WCA) was determined by monitoring the light-dependent oxygen uptake with $\mathrm{H}_{2} \mathrm{O}$ as the electron donor and $\mathrm{MV}$ as the electron acceptor in $3 \mathrm{~mL}$ Chu-10 medium containing $25 \mathrm{mM}$ BTP (pH 7.8), $1 \mathrm{mM} \mathrm{NaN}_{3}$, and 0.1 $\mathrm{mM} \mathrm{MV}$.

\subsection{Nitrogen source uptake by the organism}

The uptake of nitrate, nitrite or ammonium by the organism was studied by their depletion of $\mathrm{N}$ source from the liquid medium with time. Cyanobacterial suspension after two washings with double distilled water was added separately in media containing nitrate as potassium nitrate, nitrite as potassium nitrite $\left(100 \mu \mathrm{mol} \mathrm{L} \mathrm{L}^{-1}\right.$ each) or ammonium as ammonium chloride $\left(200 \mu \mathrm{mol} \mathrm{L}{ }^{-1}\right)$, and incubated under light for $6 \mathrm{~h}$. After separating the cells by centrifugation at $5000 \mathrm{~g}$, the residual amount of nitrate, nitrite or ammonium in the medium was determined according to the methods of Robinson et al. [29], Nicholson and Nason [30] and Solarzano [31], respectively. The nitrate, nitrite and ammonium uptake was expressed as $\mu \mathrm{mol}$ nitrate/ nitrite/ ammonium $\mathrm{mg}^{-1}$ protein.

\subsection{Enzyme assays}

The whole cell nitrate reductase (NR) activity was assayed as rate of nitrate reduction with sodium dithionite and reduced methyl viologen as the electron donor [32]. One millilitre cell suspension, after three washings with double distilled water, was treated with $20 \mu \mathrm{L}$ toluene by agitating for $3 \mathrm{~min}$ and toluene treated permeablized cells were used as enzyme extract. The reaction mixture contained in a final volume of $1 \mathrm{~mL}, 0.2 \mathrm{~mL}$ enzymes extract; $\mathrm{NaHCO}_{3}-\mathrm{Na}_{2} \mathrm{CO}_{3}$ buffer ( $\mathrm{pH} 10.5,100 \mu \mathrm{mol}$ ); $\mathrm{KNO}_{3}, 20 \mu \mathrm{mol}$; methyl viologen, $4 \mu \mathrm{mol}$; and $10 \mu \mathrm{mol}$ of sodium dithionite (freshly prepared in $0.3 \mathrm{M} \mathrm{NaHCO}$ buffer). The reaction mixture was incubated at $30{ }^{\circ} \mathrm{C}$ for $10 \mathrm{~min}$ and amount of nitrite formed was estimated. NR activity is expressed as nmol nitrite formed $\mathrm{mg}^{-1}$ protein $\mathrm{min}^{-1}$. The same procedure was followed for measuring nitrite reductase $(\mathrm{NiR})$ activity except that $\mathrm{KNO}_{3}$ was replaced by $\mathrm{KNO}_{2}$ in the reaction mixture and decrease in the amount of nitrite was estimated. NiR activity is expressed as nmol nitrite decreased $\mathrm{mg}^{-1}$ protein $\mathrm{min}^{-1}$.

Whole cell glutamine synthetase (GS) activity was measured following Shapiro and Stadtman [33]. Washed cyanobacterial cells were suspended in $1 \mathrm{~mL}$ of imidazole- $\mathrm{HCl}$ buffer (50 mM, pH 7.0). To this suspension, $20 \mu \mathrm{L}$ of toluene was added and agitated for $3 \mathrm{~min}$. The toluene treated cells were separated by centrifugation at $5000 \mathrm{~g}$ and resuspended in imidazole- $\mathrm{HCl}$ buffer and used directly as enzyme extract. The assay mixture in a total volume of $2 \mathrm{~mL}$ contains $0.8 \mathrm{~mL} 50 \mathrm{mM}$ imidazole- $\mathrm{HCl}$ buffer ( $\mathrm{pH} 7.0), 1 \mathrm{~mL}$ assay mixture $(50 \mathrm{mM}$ Imidazole buffer, $0.1 \mathrm{M}$ glutamine, $0.1 \mathrm{M}$ manganese chloride, 0.01M ADP, $1 \mathrm{M}$ sodium arsenate and $2 \mathrm{~N}$ hydroxylamine hydrocholoride neutralized with $2 \mathrm{~N}$ sodium hydroxide), and 0.2 $\mathrm{mL}$ enzyme extract. The assay mixture was incubated at $37{ }^{\circ} \mathrm{C}$ for $30 \mathrm{~min}$. The reaction was terminated by adding $4 \mathrm{~mL}$ stop mixture (prepared by mixing $4 \mathrm{~mL}$ ferric chloride (10\%), $1 \mathrm{~mL}$ of trichloro-acetic acid (24\%), $0.5 \mathrm{~mL}$ of $6 \mathrm{~N} \mathrm{HCL}$ and $6.5 \mathrm{~mL}$ of double distilled water). The absorbance of brown colour developed was measured at $540 \mathrm{~nm}$. L-glutamic acid $\gamma$-monohydroxamate was used to construct a standard curve. The GS activity is expressed as $\mu \mathrm{mol}$ of $\gamma$-glutamyl hydroxamate formed $\mathrm{mg}^{-1}$ protein $\min ^{-1}$.

\subsection{Chemicals}

All chemicals used in media preparation and analytical assays were obtained from Merck, India. Commercial grade herbicide Pretilachlor (Rifit 50\% EC) manufactured by Syngenta Chemicals Limited, Maharashtra, India was used in the present study.

\subsection{Statistical Analysis}

Data were statistically analyzed by applying one way ANOVA and Tukey's post-hoc test at 95\% confidence level ( $\mathrm{p}<$ 0.05 ) using GraphPad Prism 5.0 version 5.4. Data are average \pm SD of three independent experiments.

\section{RESULTS AND DISCUSSION}

\subsection{Tolerance limit of organism towards Pretilachlor}

The cyanobacterium Synechocystis sp. PUPCCC 64 employed in the present study is a natural inhabitant of paddy fields of Punjab, India and is an isolate of our laboratory [11]. The strain was grown in graded concentrations $\left(5-40 \mathrm{mg} \mathrm{L}^{-1}\right)$ of Pretilachlor to study its tolerance limit. The results revealed that the herbicide caused concentration dependant decrease in the growth of the test microorganism. The microorganism exhibited $15,35,55,80,90$ and $92 \%$ inhibition in growth in 5, 10, 15, 20, 25 , and $30 \mathrm{mg} \mathrm{L}^{-1}$ of Pretilachlor, respectively (Fig. 2). The organism did not grow in $40 \mathrm{mg}$ Pretilachlor $\mathrm{L}^{-1}$. Microscopic observations of cultures grown in this concentration of herbicide revealed that nearly $99 \%$ of cells were lysed and pigments were released in medium. Pretilachlor concentration dependent increase in generation time from $110 \mathrm{~h}$ in $5 \mathrm{mg} \mathrm{L}^{-1}$ to $235 \mathrm{~h}$ in $25 \mathrm{mg} \mathrm{L}^{-1}$ with simultaneously decrease in growth rate constant confirm dose dependent inhibition of growth of the test organism (Fig. 3). Similar inhibitory effects by other herbicides in cyanobacteria have been reported. The herbicides shown to affect growth of 
cyanobacteria include Butachlor, Bensulfuron-methyl and Dimethoate in Nostoc [16,28], Glyphosate in Anabaena sp., Leptolyngbya boryana, Nostoc punctiforme, Microcystis sp. and Microcystis aeruginosa [34,35], Molinate and Bentazon in Anabaena cylindrica and Nostoc muscorum [14,15], Atrazine and DCMU in Anabaena variabilis [18], Anilofos in Oscillatoria simplicissima [36] and Anabaena torulosa [20]. The inhibition of growth varied with the type of cyanobacteria and herbicide employed.

The inhibition in growth of the present strain may be due to the damaging effect of herbicide on photosynthetic machinery, protein and or DNA molecules [37, 38]. Since the organism exhibited nearly $55 \%$ growth in $15 \mathrm{mg}$ Pretilachlor $\mathrm{L}^{-1}$ which is 11 times the recommended field application concentration of Pretilachlor as compared to control cultures, it indicated that organism exhibit significant tolerance to herbicide.

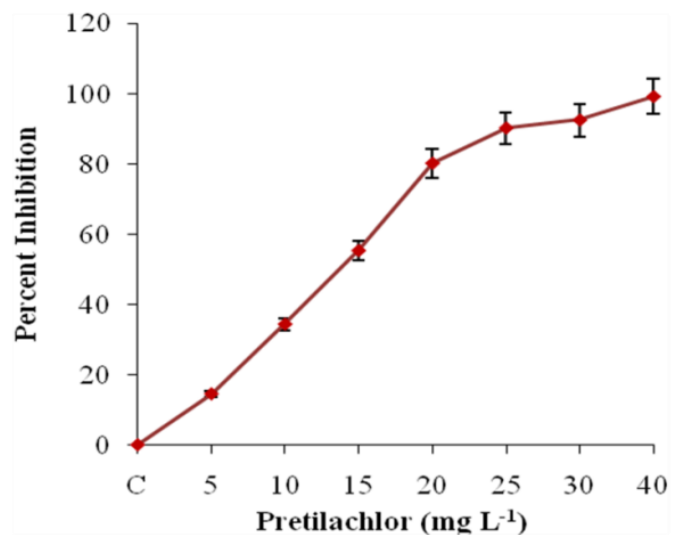

Fig. 2: Inhibition in growth $\left(\mathrm{A}_{680}\right)$ of Synechocystis in presence of Pretilachlor on day 6.

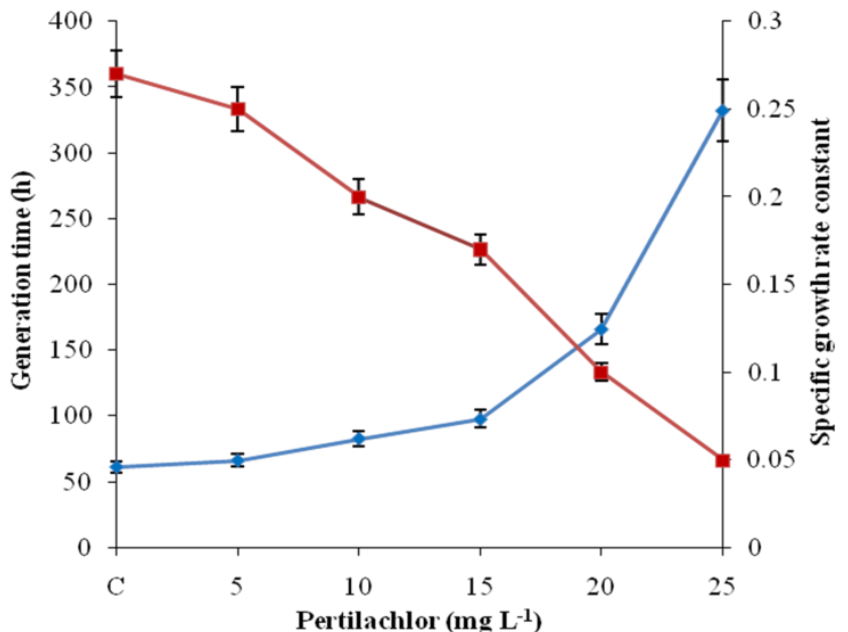

Fig. 3: Specific growth rate constant and generation time of Synechocystis in presence of Pretilachlor.

In order to understand the mechanism of growth inhibition in Synechocystis sp., the impact of Pretilachlor on total soluble proteins, photosynthetic pigments, photosynthesis, respiration and $\mathrm{N}$ assimilation were analysed. For this, three concentrations of Pretilachlor i.e. 10,15 and $20 \mathrm{mg} \mathrm{L}^{-1}$ were chosen.

\subsection{Protein content}

The total protein content of control cultures of Synechocystis increased from $4.46 \mu \mathrm{g}$ per $10^{6}$ cells on zero day to $10.5 \mu \mathrm{g} 10^{6}$ cells $^{-1}$ on day 6 . Pretilachlor concentration dependent decrease in protein content of the organism was observed. The test organism exhibited $14.5,33.8$ and $52.4 \%$ decrease in total protein content compared to control cultures in 10, 15 and $20 \mathrm{mg}$ herbicide $\mathrm{L}^{-1}$ (Fig. 4). Supplementation of Butachlor (8-20 mg L $\left.{ }^{-1}\right)$ in culture medium of Nostoc muscorum resulted in decrease of protein content by $27-89 \%$ whereas 14 and $63 \%$ decrease in protein content in 5 and $8 \mathrm{mg}$ Thiobencarb $\mathrm{L}^{-1}$ was reported [39]. Of the three herbicides studied, Glyphosate, Pretilachlor and Propanil, only Propanil (0.187-1.5 $\left.\mathrm{mg} \mathrm{L}^{-1}\right)$ significantly inhibited protein content of Anabaena fertilissima [40]. Carbaryl (40 $\mathrm{mg} \mathrm{L}^{-1}$ ) decreased content of protein by $40 \%$ in a paddy field cyanobacterium Calothrix brevissima [41]. The decrease in protein content of the test organism in varied concentration of Pretilachlor may be due to its interference with structure and function of membrane proteins or photosynthetic machinery of cells such as photosynthetic pigments, PS-I and PS-II or nitrogen assimilation $[12,42,43]$. Thus, the affect of Pretilachlor on photosynthetic pigments, photosynthesis, respiration and nitrogen assimilation was studied.

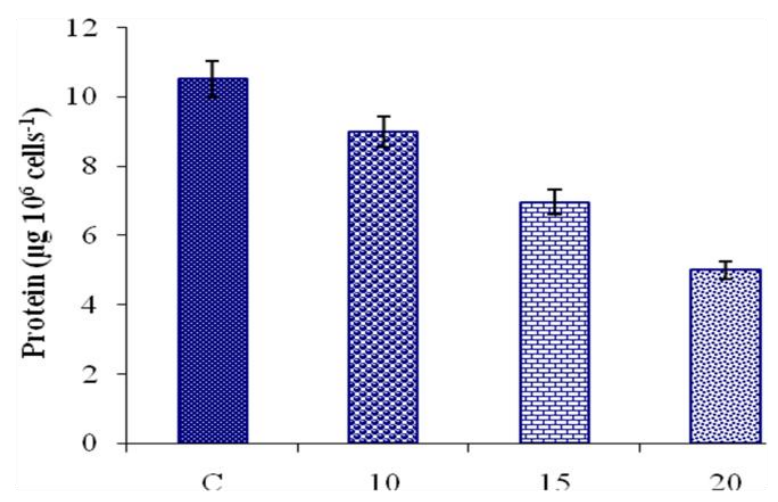

Fig. 4: Effect of Pretilachlor $\left(\mathrm{mg} \mathrm{L}^{-1}\right)$ on total protein content of Synechocystis on day 6. C: Control. Data in figure are significantly different from each other at $95 \%$ confidence level ( $p<0.05$ ).

\subsection{Photosynthetic pigments}

Pretilachlor caused a significant decrease in chlorophyll (Chl) $a$, carotenoids, phycocyanin (PC), allophycocyanin (APC) and phycoerythrin (PE) content in a dose dependent manner compared to control with more pronounced effects at higher concentrations of Pretilachlor (Figs 5 and 6). Chl $a$ content of Synechocystis sp., on day six, in $20 \mathrm{mg}$ Pretilachlor $\mathrm{L}^{-1}$ was decreased by $49 \%$. In the same concentration of the herbicide, carotenoids decreased by $76 \%$ while PC, APC and PE were decreased by $52 \%, 61 \%$ and $50 \%$, respectively, compared to control cultures. The order of decrease in photosynthetic pigments was Carotenoids $>\mathrm{APC}>\mathrm{PC}>\mathrm{PE}>\mathrm{Chl} a$. It is interesting to 
note that in $10 \mathrm{mg}$ Pretilachlor $\mathrm{L}^{-1}$ which is 7 times the recommended field application dose, levels of photosynthetic pigments decreased in the range of 13-25\% only (Fig. 5 and 6). Growth inhibition of Synechocystis with increase in Pretilachlor concentration could be explained on the basis of damaging effect of herbicide on photosynthetic pigments. Bensulfuron methyl, Butachlor and Dimethoate inhibited photosynthetic pigments of Nostoc [28]. Treatment of Anabaena cylindrica with Bentazon (2 $\mathrm{mM}$ ) for $72 \mathrm{~h}$ decreased total phycobiliproteins by $58 \%$ where as Molinate at highest tested concentration ( $2 \mathrm{mM})$ completely suppressed phycobiliproteins after $24 \mathrm{~h}$ treatment [15]. Anilofos inhibited all photosynthetic pigments of Anabaena torulosa [20], Oscillatoria simplicissima [36] and even of the test organism [12].

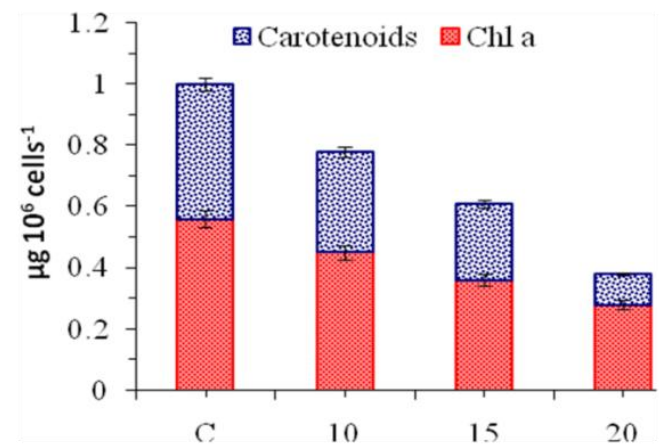

Fig. 5: Effect of Pretilachlor $\left(\mathrm{mg} \mathrm{L}^{-1}\right)$ on acetone soluble photosynthetic pigments of Synechocystis on day 6. C: Control. Data in figure are significantly different from each other at $95 \%$ confidence level $(p<0.05)$.

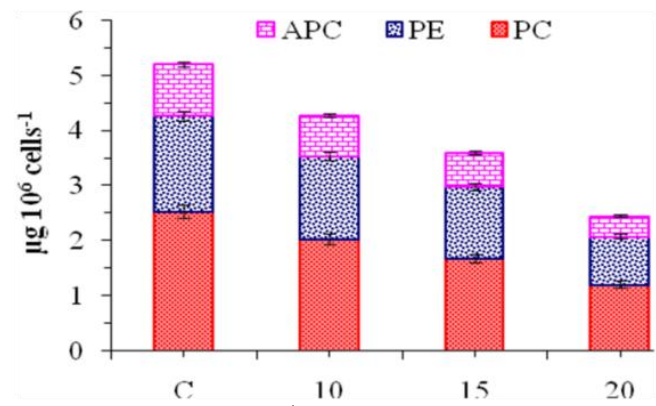

Fig. 6: Effect of Pretilachlor $\left(\mathrm{mg} \mathrm{L}^{-1}\right)$ on water soluble photosynthetic pigments of Synechocystis on day 6. C: Control. Data in figure are significantly different from each other at $95 \%$ confidence level $(p<0.05)$.

\subsection{Photosynthetic and respiratory activities}

The growth and development of photoautotrophs depend upon photosynthesis [44]. Decreased growth of the Synechocystis in the presence of Pretilachlor may also be as a result of low photosynthetic activities due to the loss of photosynthetic pigments. To ascertain this, the effect of Pretilachlor on photosynthetic rate was studied. Whole cell photosynthetic $\mathrm{O}_{2}$ evolution and photosynthetic electron transport activity of the test organism were significantly affected by Pretilachlor in a dose dependent manner. Treatment of the organism with $20 \mathrm{mg}$ Pretilachlor $\mathrm{L}^{-1}$ for $12 \mathrm{~h}$ caused $48.8 \%$ reduction in rate of photosynthesis over control cultures (Table 1). Decrease in photosynthetic $\mathrm{O}_{2}$ evolution in Anabaena torulosa has also been reported in the presence of Anilofos [20]. Kim and Lee [45] observed that Bensulfuron-methyl (5 $\left.\mathrm{mg} \mathrm{L} \mathrm{L}^{-1}\right)$ suppressed photosynthesis of Nostoc commune by $32 \%$. The treatment with pure $\left(8 \mathrm{mg} \mathrm{L}^{-1}\right)$ and formulation $\left(4 \mathrm{mg} \mathrm{L}^{-1}\right)$ forms of Atrazine and DCMU $\left(0.6 \mathrm{mg} \mathrm{L}^{-1}\right)$ caused $80-87 \%$ inhibition in photosynthetic $\mathrm{O}_{2}$ evolution in wild and multiple herbicide resistant strain of Anabaena variabilis [18]. Herbicides inhibit photosynthesis mainly by preventing electron flow from PS-II both in algae as well as in higher plants [46-48]. In higher plants, herbicides have been shown to be uncouplers of photophosphorylation [49]. The effect of Pretilachlor on photosynthetic electron transport activity (PS-I, PS-II and WCA) of the strain PUPCCC 64 was dose dependent. It was observed that $20 \mathrm{mg}$ Pretilachlor $\mathrm{L}^{-1}$ reduced PSI, PS-II activities and WCA by $39 \%, 43 \%$ and $38 \%$, respectively (Table 1). It appears that Pretilachlor reduced the energy transfer from phycobilisomes to PS II, as reported earlier in Anabaena doliolum in the presence of Glyphosate [50]. The photochemical activities of the Anabaena torulosa were significantly inhibited by herbicide Anilofos [20]. Significant decrease in photochemical activities of the test microorganism under Pretilachlor stress may lead to the reduction of photophosphorylation as reported in Plectonema boryanum under Endosulfan stress [51].

The inhibitory effect of Pretilachlor on respiration in Synechocystis sp. was also dose dependent. The test microorganism exhibited 59\% decrease in the rate of respiration in $20 \mathrm{mg}$ Pretilachlor $\mathrm{L}^{-1}$ compared to control cultures (Table 1).

Table 1: Effect of Pretilachlor $\left(\mathrm{mg} \mathrm{L}^{-1}\right)$ on photosynthesis, respiration and photochemical activities of Synechocystis after $12 \mathrm{~h}$ treatment.

\begin{tabular}{|c|c|c|c|c|c|}
\hline Treatments & $\begin{array}{l}\text { Photosynthesis } \\
\left(\mu \mathrm{mol} \mathrm{O}_{2} \text { evolved }\right. \\
\left.\mathrm{mg}^{-1} \mathrm{Chl} a \mathrm{~min}^{-1}\right)\end{array}$ & $\begin{array}{l}\text { Photosystem I } \\
\left(\mu \mathrm{mol} \mathrm{O}_{2} \text { consumed } \mathrm{mg}^{-1}\right. \\
\left.\text { Chl } a \mathrm{~min}^{-1}\right)\end{array}$ & $\begin{array}{l}\text { Photosystem II } \\
\left(\mu \mathrm{mol} \mathrm{O}_{2} \text { evolved } \mathrm{mg}^{-1}\right. \\
\left.\text { Chl } a \min ^{-1}\right)\end{array}$ & $\begin{array}{l}\text { Whole Chain Activity } \\
\left(\mu \mathrm{mol} \mathrm{O}_{2} \text { evolved } \mathrm{mg}^{-1} \mathrm{Chl}\right. \\
\left.a \mathrm{~min}^{-1}\right)\end{array}$ & $\begin{array}{l}\text { Respiration } \\
\left(\mu \mathrm{mol} \mathrm{O}_{2} \text { consumed }\right. \\
\left.\mathrm{mg}^{-1} \mathrm{Chl} a \mathrm{~min}^{-1}\right)\end{array}$ \\
\hline $\mathbf{C}$ & $70.00 \pm 2.78$ & $35.2 \pm 2.65$ & $54.7 \pm 3.15$ & $77.4 \pm 3.20$ & $54.40 \pm 3.28$ \\
\hline 10 & $61.00 \pm 2.17(\mathbf{1 5 . 8 0})$ & $25.8 \pm 1.67(\mathbf{2 6 . 7 0})$ & $46.1 \pm 2.16(\mathbf{1 5 . 7 2})$ & $72.6 \pm 2.65(6.20)$ & $46.30 \pm 2.15(\mathbf{2 4 . 0 0})$ \\
\hline 15 & $55.80 \pm 2.99(\mathbf{2 8 . 8 5})$ & $24.9 \pm 2.27(\mathbf{2 9 . 2 6})$ & $35.2 \pm 2.19(\mathbf{3 5 . 6 4})$ & $54.4 \pm 2.67(\mathbf{2 9 . 7 1})$ & $42.13 \pm 2.16(46.69)$ \\
\hline 20 & $42.80 \pm 1.85(\mathbf{4 8 . 8 5})$ & $21.4 \pm 1.81(39.20)$ & $31.1 \pm 2.17(43.14)$ & $47.9 \pm 2.75(\mathbf{3 8 . 1 1})$ & $35.40 \pm 2.87(\mathbf{5 8 . 8 2})$ \\
\hline
\end{tabular}

Data given in parenthesis indicate percent inhibition over untreated control culture. C: Control. Data in each row and column are significantly different from each other at the $95 \%$ confidence level $(\mathrm{P}<0.05)$. 
Table 2: Effect of Pretilachlor $\left(\mathrm{mg} \mathrm{L}^{-1}\right)$ on nitrogen assimilating enzymes of Synechocystis after $12 \mathrm{~h}$ treatment.

\begin{tabular}{|c|c|c|c|c|c|c|}
\hline \multirow[t]{2}{*}{ Treatments } & \multirow{2}{*}{$\begin{array}{c}\text { NR Activity } \\
\text { (nmol nitrite formed } \\
\text { mg }^{-1} \text { protein } \text { min }^{-1} \text { ) }\end{array}$} & \multicolumn{2}{|c|}{$\begin{array}{c}\text { NiR Activity } \\
(\text { nmol nitrite decreased } \\
\left.\mathrm{mg}^{-1} \text { protein } \text { min }^{-1}\right) \\
\end{array}$} & \multicolumn{3}{|c|}{$\begin{array}{c}\text { GS Activity } \\
\text { (nmol } \gamma \text {-glutamyl hydroxamate formed } \\
\mathrm{mg}^{-1} \text { protein } \mathrm{min}^{-1} \text { ) } \\
\end{array}$} \\
\hline & & Nitrate & Nitrite & Nitrate & Nitrite & Ammonium \\
\hline $\mathbf{C}$ & $37.86 \pm 3.61$ & $33.33 \pm 3.27$ & $48.62 \pm 3.29$ & $2.67 \pm 0.86$ & $3.25 \pm 1.21$ & $3.6 \pm 1.16$ \\
\hline 10 & $34.98 \pm 3.76(\mathbf{7 . 6 0})$ & $30.57 \pm 2.65(\mathbf{8 . 2 8})$ & $45.46 \pm 3.26(6.49)$ & $2.31 \pm 0.78(\mathbf{1 3 . 4 8})$ & $2.86 \pm 0.23(\mathbf{1 2 . 0})$ & $3.14 \pm 1.21(\mathbf{1 3 . 8 8})$ \\
\hline 15 & $32.38 \pm 3.27(\mathbf{1 4 . 4 7 )}$ & $27.76 \pm 2.14(\mathbf{1 6 . 7 1 )}$ & $42.10 \pm 3.17(\mathbf{1 3 . 4 1})$ & $2.07 \pm 0.94(\mathbf{2 2 . 4 7})$ & $2.56 \pm 0.38(\mathbf{2 1 . 2 3})$ & $2.73 \pm 0.35(\mathbf{2 5 . 0})$ \\
\hline 20 & $28.81 \pm 2.17(\mathbf{2 3 . 9 0})$ & $24.87 \pm 2.15(25.38)$ & $38.57 \pm 3.22(\mathbf{2 0 . 6 7})$ & $1.75 \pm 0.049(\mathbf{3 0 . 7 1})$ & $2.20 \pm 0.43(\mathbf{3 2 . 3 0})$ & $2.34 \pm 0.47(\mathbf{3 6 . 0})$ \\
\hline
\end{tabular}

Data given in parenthesis indicate percent inhibition over untreated control culture. C: Control. Data in each column are significantly different from each

These observations indicate that Pretilachlor affected not only photosynthesis but respiration of the organism as well though to less extent. Similar observations have been reported in other organism with other pesticides. Anilofos (1.25-5.0 $\left.\mathrm{mg} \mathrm{L}^{-1}\right)$ caused a decrease in respiration rate in Anabaena torulosa [20]. Chen et al. [28] also reported decrease in the rate of respiration in Nostoc when treated with Bensulfuron methyl, Butachlor, and Dimethoate. Thus, it would be interesting to study at what step(s) the Pretilachlor interferes with the respiration process of the test organism.

\subsection{Nitrogen uptake studies}

Cyanobacteria may use nitrate, nitrite or ammonium as a nitrogen source for growth and development. Many of them, especially heterocystous forms, are able to fix atmospheric nitrogen [52]. Nitrogen assimilation in cyanobacteria is photosynthesis dependent. Thus, the effect of Pretilachlor on nitrogen assimilation was studied. Pretilachlor caused dose dependent effect on nitrogen up take by Synechocystis sp. The treatment of the test organism with $20 \mathrm{mg}$ Pretilachlor $\mathrm{L}^{-1}$ caused nearly $50 \%$ inhibition in nitrate and nitrite uptake (Fig. 7).

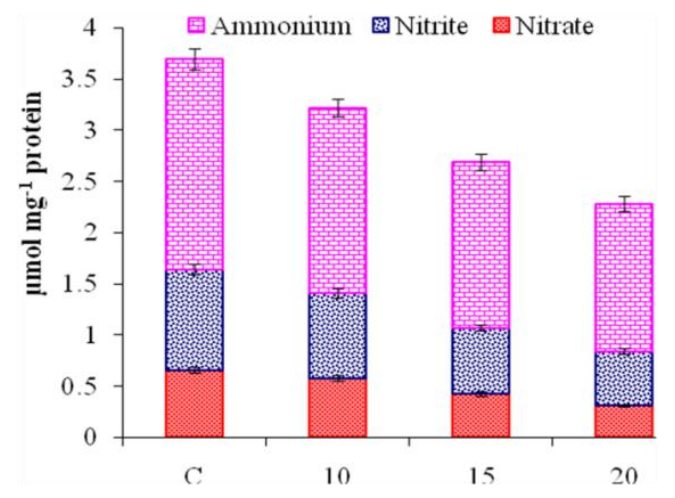

Fig. 7: Effect of Pretilachlor $\left(\mathrm{mg} \mathrm{L}^{-1}\right)$ on nitrogen uptake by Synechocystis after $6 \mathrm{~h}$ treatment. C: Control. Data in figure are significantly different from each other at $95 \%$ confidence level $(\mathrm{p}<0.05)$.

Photosynthetically reduced ferredoxin serves as an electron donor for nitrate reduction in cyanobacteria [53]. Thus, decrease in photosynthesis caused by Pretilachlor may have resulted in low uptake and reduction of nitrate in this organism. Ammonium uptake by the test organism was also significantly reduced (32.88\%) by $20 \mathrm{mg}$ Pretilachlor $\mathrm{L}^{-1}$ (Fig. 7). It has been demonstrated that ammonium uptake in cyanobacteria is a membrane potential driven transport process [54]. It may be that Pretilachlor interfered with the membrane potential of this organism and resulted in reduced ammonium uptake.

\subsection{Activity of nitrogen assimilation enzymes}

Three enzymes, nitrate reductase (NR), nitrite reductase (NiR) and glutamine synthetase (GS) of Synechocystis sp. strain PUPCCC 64 were chosen to study the effect of Pretilachlor on N assimilation. Activities of both NR and NiR were significantly reduced by Pretilachlor in a dose dependent manner (Table 2).

The reduction in NR activity was $24 \%$ in $20 \mathrm{mg}$ Pretilachlor $\mathrm{L}^{-1}$ treated cultures compared to control cultures. Effect of Pretilachlor on NiR activity of the strain PUPCCC 64 was studied in nitrate and nitrite grown cells. The test organism exhibited $21 \%$ inhibition in NiR activity of nitrite grown cells. NR and NiR are membrane bound enzymes and their activity depends on reduced ferredoxin produced during photosynthesis [55]. Decreased activities of these enzymes in presence Pretilachlor may be due to its interference with ferredoxin reduction or at uptake level of nitrate or nitrite. The progressive decrease in NR and NiR activities of Nostoc muscorum by carbaryl (5-50 $\mathrm{mg} \mathrm{L}^{-1}$ ) and Anabaena fertilissima by Endosulfan (3-12 $\mathrm{mg} \mathrm{L}^{-1}$ ) has been reported [56,57]. Ammonium produced by the activities of NR and NiR or taken up directly is assimilated by the activity of glutamine synthetase (GS) through GS-GOGAT cycle [52]. Thus, effect of herbicide on GS activity of cells grown in nitrate, nitrite or ammonium was studied. Similar to the effect on NR and NiR, GS activity also decreased by $31 \%$ in $20 \mathrm{mg}$ Pretilachlor $\mathrm{L}^{-1}$ as compared to control cultures. The pattern of effect of Pretilachlor on GS activity of nitrite and ammonium grown cells of the test organism was similar to nitrate grown cells. GS activity decreased by $32 \%$ when cells were grown in nitrate medium with $20 \mathrm{mg}$ Pretilachlor $\mathrm{L}^{-1}$. In ammonium grown cultures, GS activity of Synechocystis decreased by $36 \%$ in presence of herbicide (Table 2 ). Among all the nitrogen sources, the effect of Pretilachlor was more pronounced on GS activity of cells grown in ammonium supplemented medium. GS activity depends upon the amount of ammonium ions taken up by the cells or produced by reduction of nitrate by NR followed by NiR reduction. Thus, decrease in GS activity appears to be correlated with reduction in nitrate/ 
ammonium uptake rather than direct toxic effects of Pretilachlor on GS activity. The decrease in GS activity in cyanobacteria caused by other pesticides has been reported [56, 58]. Treatment of Anabaena torulosa with 1.25- $5 \mathrm{mg}$ Anilofos $\mathrm{L}^{-1}$ caused 9-22\% decrease in GS activity [20].

\section{CONCLUSIONS}

Pretilachlor at $20 \mathrm{mg} \mathrm{L}^{-1}$ concentration which is 15 times higher than recommended field application dose, adversely affected the growth of Synechocystis by reducing photosynthetic pigments, photosynthesis and respiration. The suppression of photosynthesis under the influence of Pretilachlor appears to be responsible for low uptake of nitrogen compounds and lowered activity of nitrogen assimilation enzymes. Since at low dose (10 $\mathrm{mg} \mathrm{L}^{-1}$ ) of Pretilachlor, these physiological processess were not adversely affected, the test organism can be made a part of biofertilizer programme for Pretilachlor applied fields.

\section{ACKNOWLEDGMENT}

The authors thank Head and Coordinator, DRS-SAP-II of UGC, Department of Botany, Punjabi University, Patiala for infrastructure and laboratory facilities.

\section{REFERENCES}

1. Ash C, Jasny BR, Malakoff DA \& Sugden AM. Feeding the future. Science. 2010; 327: 797.

2. Anonymous. Editorial - How to feed a hungry world? Nature. 2010; 466: 531-532.

3. Normile D. Reinventing rice to feed the world. Science. 2008; 321: 330-331.

4. Monaco TJ, Weller SC \& Ashton FM. Weed Science: Principles and Practices, $4^{\text {th }}$ Ed. New York: John Wiley \& Sons; 2002.

5. Olofsdotter M, Watson A \& Piggin C. Weeds: A looming problem in modern rice production. In: N G Dowling, SM Greenfield \& KS Fisher (Editors). Sustainability of Rice in the Global Food System. Davis, Calfornia (USA): Pacific Basin Study Center, 1998. p. 165-173.

6. Fernández-Valiente EA, Ucha A, Quesada F, Leganés, \& Carreres R. Contribution of $\mathrm{N}_{2}$ fixing cyanobacteria to rice production: availability of nitrogen from ${ }^{15} \mathrm{~N}$-labelled cyanobacteria and ammonium sulphate to rice. Plant Soil. 2000; 221: 107-112.

7. Mishra U \& Pabbi S. Cyanobacteria a potential biofertilizer for rice. Resonance. 2004; 9: 6-10.

8. Singh S \& Datta P. Outdoor evaluation of herbicide resistant strains of Anabaena variabilis as biofertilizer for rice plants. Plant Soil. 2007; 296: 95-102.

9. Tiwari DN, Kumar A \& Mishra AK. Use of cyanobacterial diazotrophic technology in rice agriculture. Applied Biochemistry and Biotechnology.1991; 28/29: 387-396.

10. Whitton BA \& Potts M. Introduction to cyanobacteria. In: BA Whitton, M Potts (Editors). The Ecology of Cyanobacteria: Their Diversity in Time and Space. The Netherlands: Kluwer Academic Press. 2000. p.1-11.

11. Singh DP, Khattar JIS, Nadda J. Singh Y, Garg A, Kaur N, \& Gulati A. Chlorpyrifos degradation by the cyanobacterium Synechocystis sp. strain PUPCCC 64. Environmental Science and Pollution Research. 2011; 18: 1351-1359.

12. Singh DP, Khattar JIS, Kaur M, Kaur G, Gupta M \& Singh Y. Anilofos tolerance and its mineralization by the cyanobacterium Synechocystis sp. strain PUPCCC 64. PLoS One. 2013; 8: e53445
13. Xia J. Response of growth, photosynthesis and photoinhibition of the edible cyanobacterium Nostoc sphaeroides colonies to thiobencarb herbicide. Chemosphere.2005; 59: 561-566.

14. Galhano V, Peixoto F, Gomes-Laranjo J \& Fernández -Valiente E. Comparative toxicity of bentazon and molinate on growth, photosynthetic pigment, photosynthesis and respiration of portuguese rice field cyanobacterium Nostoc muscorum. Environmental Toxicology. 2010; 25: 147-156.

15. Galhano V, Peixoto F, Gomes-Laranjo J \& Fernández-Valiente E. Differential effects of bentazon and molinate on Anabaena cylindrica, an autochthonous cyanobacterium of Portuguese rice field agroecosystem. Water, Air and Soil Pollution. 2010; 197: 211-222.

16. Selvakumar G, Gopalaswamy G \& Kannaiyan S. Pigment analysis and ammonia excretion in herbicide tolerant cyanobacteria. Indian Journal of Experimental Biology. 2002; 40: 934-940.

17. Agrawal C, Sen S, Singh S, Rai S, Singh PK, Singh VK \& Rai LC. Comparative proteomics reveals association of early accumulated proteins in conferring butachlor tolerance in three $\mathrm{N}_{2}$-fixing Anabaena spp. Journal of Proteomics. 2014; 96: 271-290.

18. Singh S, Datta P \& Tirkey A. Response of multiple herbicide resistant strain of diazotrophic cyanobacterium, Anabaena variabilis, exposed to atrazine and DCMU. Indian Journal of Experimental Biology. 2011; 49: 298-303.

19. Chen L, Xie M, Bi M, Wang G, Deng S \& Liu Y. The combined effects of UV-B radiation and herbicides on photosynthesis, antioxidant enzymes and DNA damage in two bloom-forming cyanobacteria. Ecotoxicology and Environmental Safety. 2012; 80: 224-230.

20. Singh DP, Khattar JIS, Kaur K, Sandhu BS \& Singh Y. Toxicological impact of anilofos on some physiological processes of a rice field cyanobacterium Anabaena torulosa. Toxicological and Environmental Chemistry. 2012; 94: 1304-1318.

21. Han $\mathrm{S} \&$ Hatzios KK. Uptake, translocation and metabolism of $\left[{ }^{14} \mathrm{C}\right]$ pretilachlor in fenclorim-safened and unsafened rice seedlings. Pesticide Biochemistry and Physiology. 1991; 39: 281-290.

22. Gill MS \& Bajwa HS. Package of practices for crops of Punjab kharif. Ludhiana: Punjab Agriculture University; 2012.

23. Safferman RS \& Morris ME. Growth characteristics of the blue green algal virus LPP-1. Journal Bacteriology. 1964; 88: 771-775.

24. Myers J \& Kratz WA. Relationship between pigment content and photosynthetic characteristics in a blue green algae. Journal of General Physiology. 1955; 39: 11-21.

25. Lowry OH, Rosebrough NJ, Farr AL \& Randall RJ. Protein measurement with the folin phenol reagent. The Journal of Biological Chemistry. 1951; 193: 265-275.

26. Holm G. Chlorophyll mutations in barley. Acta Agriculturae Scandinavica. 1954; 49: 457-470.

27. Bennett A \& Bogorad L. Complementary chromatic adaptation in a filamentous blue-green alga. Journal of Cell Biology. 1973; 58:419-35

28. Chen Z, Juneau P. \& Qiu B. Effects of three pesticides on the growth, photosynthesis and photoinhibition of the edible cyanobacterium $\mathrm{Ge}$ Xian-Mi (Nostoc). Journal of Aquatic Toxicology. 2007; 81: 256-265.

29. Robinson JBD, Allen M de V \& Gacoka P. The determination of soil nitrates with a brucine reagent. Analyst. 1959; 84: 635-640.

30. Nicholas DJ \& Nason A. Determination of nitrate and nitrite. Methods of Enzymology. 1957; 3: 981-984.

31. Solorzano L. Determination of ammonia in natural waters by the phenol hypochlorite method. Limnology and Oceanography. 1969; 14: 799-801.

32. Herrero A, Flores E, \& Guerrero MG. Regulation of nitrate reductase levels in the cyanobacteria Anacystis nidulans, Anabaena sp. strain 7119 and Nostoc sp. strain 6719. Journal of Bacteriology. 1981; 145: 175-180.

33. Shapiro BM \& Stadtman ER. Glutamine synthetase of Escherchia coli. In: H Tabor, CW Tabor (Editors) Methods of Enzymology Vol. XVII A, New York; Academic Press. 1970. p. 910-922.

34. Rodas VL, Moya AF, Maneiro E, Perdigones N, Marva F, García ME, \& Costas E. Resistance to glyphosate in the cyanobacterium 
Microcystis aeruginosa as a result of pre selective mutations. Environment Ecology.2006; 21: 535-547.

35. Forlani G, Pavan M, Gramek M, Kafarski P \& Lipok J. Biochemical basis for a wide spread tolerance of cyanobacteria to the phoshonate herbicide glyphosate. Plant and Cell Physiology. 2008; 49: 443-456.

36. Singh DP \& Sandhu BS. Effect of anilofos on growth, photosynthetic pigments and stress enzymes of cyanobacterium Oscillatoria simplicissima. Research Journal of Biotechnology. 2010; 5: 27-32.

37. Li X, Ping X, Xiumei, S, Zhenbin W \& Liqiang X. Toxicity of cypermethrin on growth, pigments, and superoxide dismutase of Scenedesmus obliquus. Ecotoxicology and Environmental Safety. 2005; 60: 188-192.

38. Mishra V, Srivastava G, Prasad SM \& Abraham G. Growth, photosynthetic pigments and photosynthetic activity during seedling stage of cowpea (Vigna unguiculata) in response to UV-B and dimethoate. Pesticide Biochemistry and Physiology. 2008; 92: 30-37.

39. Dowidar SMA, Osman MEH, El-Naggar AH \& Khalefa AE. Effect of butachlor and thiobencarb herbicides on protein content, profile and some enzyme activities of Nostoc muscorum. Journal of Genetic Engineering and Biotechnology. 2010; 8: 89-95.

40. Inderjit \& Kaushik S. Effect of herbicide with different modes of action on physiological and cellular traits of Anabaena fertilissima. Paddy Water and Environment. 2010; 8: 277-282.

41. Habib K, Kumar S, Manikar N, Zutshi N \& Fatma T. Biochemical effect of carbaryl on oxidative stress, antioxidant enzymes and osmolytes of cyanobacterium Calothrix brevissima. Bulletin of Environmental Contamination and Toxicology. 2011; 87: 615-620.

42. Rajendran UM, Kathirvel E \& Narayanaswamy A. Effects of a fungicide, an insecticide, and a biopesticide on Tolypothrix scytonemoides. Pesticide Biochemistry and Physiology. 2007; 87: 164171

43. Kumar JIN, Kumar R N, Bora A \& Amb MK. Photosynthetic, biochemical and enzymatic investigation of Anabaena fertilissima in response to an insecticide hexachloro-hexahydromethanobenzodioxathiepine-oxide. Journal of Stress Physiology and Biochemistry. 2009; 5: 4-12.

44. Prasad SM, Zeeshan M \& Kumar D. Toxicity of endosulfan on growth, photosynthesis and nitrogenase activity in two species of Nostoc (Nostoc muscorum and Nostoc calcicola). Toxicologcal and Environmental Chemistry. 2011; 93: 513-525.

45. Kim JD, \& Lee CG. Differential responses of two freshwater cyanobacteria, Anabaena variabilis and Nostoc commune to sulfonylurea herbicide bensulfuron-methyl. Journal of Microbiology and Biotechnology. 2006; 16: 52-56.

46. Tischer W \& Strotmann H. Relationship between inhibitor binding by chloroplasts and inhibition of photosynthetic electron transport. Biochimica et Biophysica Acta (BBA) -Bioenergetics. 1977; 460: 113125.

47. Pfister K \& Arntzen CJ. The mode of action of photosystem-IIspecific inhibitors in herbicide resistant biotypes. Zeitschrift für Naturforschung. 1979; 34: 996-1009.
48. Allen MM, Turnburke AC, Legace EA \& Steinback KE. Effects of Photosystem II herbicides on the photosynthetic membranes of the cyanobacterium Aphanocapsa 6308. Plant Physiology.1983; 71: 388392.

49. Moreland DE. Mechanisms of action of herbicides. Annual Review of Plant Physiology. 1980; 31: 597-638.

50. Shikha \& Singh DP. Influence of glyphosate on photosynthetic properties of wild type and mutant strains of cyanobacterium Anabaena doliolum. Current Science. 2004; 86: 571-576.

51. Prasad SM, Kumar D \& Zeeshan M. Growth, photosynthesis, active oxygen species and antioxidant responses of paddy field cyanobacterium Plectonema boryanum to endosulfan stress. The Journal of General and Applied Microbiology. 2005; 51: 115-123.

52. Flores $\mathrm{E} \&$ Herrero A. Nitrogen assimilation and nitrogen control in cyanobacteria. Biochemical Society Transactions. 2005; 33: 164-167.

53. Flores E, Frias JE, Frías LM \& Herrero A. Photosynthetic nitrate assimilation in cyanobacteria. Photosynthesis Research. 2005; 83: 117 133.

54. Montesinos ML, Muro-Pastor AM, Herrero A \& Flores E. Ammonium/ methyl ammonium permeases of a cyanobacterium: Identification and analysis of three nitrogen-regulated amt genes in Synechocystis sp. PCC 6803. Journal of Biological Chemistry. 1998; 273: 31463-31470.

55. Flores E, Guerrero MG \& Losada M. Photosynthetic nature of nitrate uptake and reduction in the cyanobacterium Anacystis nidulans. Biochimica et Biophysica Acta (BBA) -Bioenergetics. 1983; 722: 408416.

56. Bhunia AK, Marik R \& Banerjee S. Biochemical effects of carbaryl on nitrogen assimilating enzymes of cyanobacteria Nostoc muscorum. Bulletin of Environmental Contamination and Toxicology. 1994; 52: 886-892.

57. Kumar NJI, Bora A, Kumar RN \& Amb MK. Differential effects of agricultural pesticides endosulfan and tebuconazole on photosynthetic pigments, metabolism and assimilating enzymes of three heterocystous, filamentous cyanobacteria. Journal of Biology and Environmental Sciences. 2012; 6: 67-75.

58. Jha MN \& Mishra SK. Biological response of cyanbobacteria to insecticides and their insecticide degrading potential. Bulletin of Environmental Contamination and Toxicology. 2005; 75: 374-381.

\section{How to cite this article:}

Singh DP, Khattar JS, Alka, Kaur G and Singh Y. Toxicological effect of pretilachlor on some physiological processes of cyanobacterium Synechocystis sp. strain PUPCCC 64. J App Biol Biotech. 2016; 4 (01): 012-019. DOI:10.7324/JABB.2016.40103 